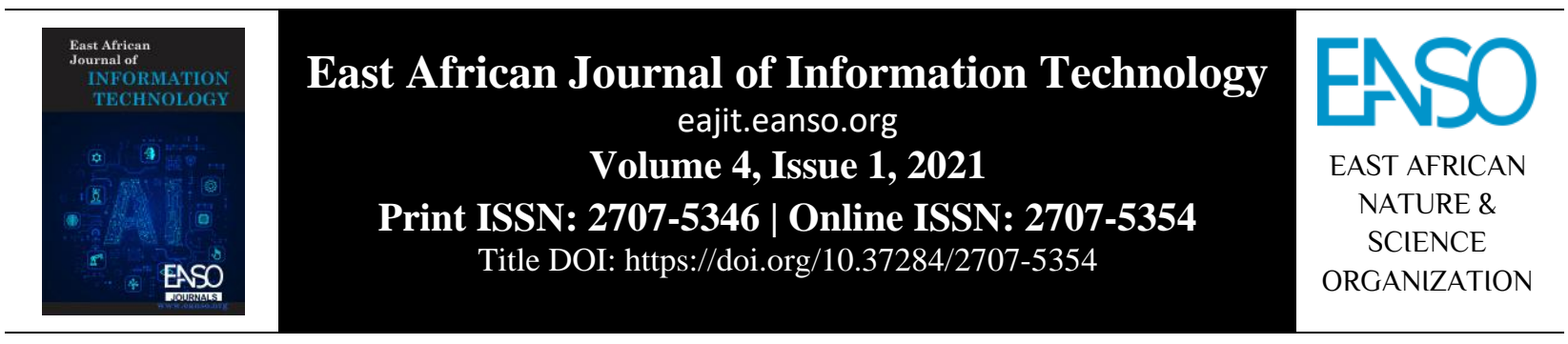

Original Article

\title{
An Analysis of Social Media Usage by Public Relations Departments in Select Private Universities in Kenya.
}

\author{
Nyabera N. Samwel ${ }^{*}$ \& Agnes Lucy Lando, PhD \\ ${ }^{1}$ St Augustine University of Tanzania, P. O. Box 307 Mwanza, Tanzania. \\ ${ }^{2}$ Daystar University, P. O. Box 44400-00100 Nairobi, Kenya. \\ * Correspondence email: s.nyabera@gmail.com.
}

Article DOI: https://doi.org/10.37284/eajit.4.1.502

Date Published: ABSTRACT

10 December 2021 This paper investigates the use of Social Media by Public Relations departments in two large private universities in Kenya. Social media are

Keywords: web-based applications where the creation of profiles and connections of

Social Media Use, people takes place. Social media use is constantly growing amongst

Public Relations,

Departments,

Public, organizations, as technology and globalization evolve, so do the role of Public Relations hence becoming inevitable in everyday practice. Despite the availability of social media platforms, little is known on how they are used to communicate. Contrariwise, the extant literature discloses that at present, there is moderately negligible research with focus on the use of Communication. social media in public relations in private organizations. This study is grounded on the outcomes of a research submitted in lieu of a Doctoral degree in Mass Communication at the St Augustine University of Tanzania involving 270 survey participants and 2 in-depth interviews. Data was generated using questionnaires and analysed using SPSS version 23 whereas interviews were analysed thematically. Findings reveal that University $\mathrm{K}$ and St Paul University use social media to: publicize activities; send information to the public; change public opinion; enhance information value; lobby public support as well as to provide the public with a question-and-answer platform. This paper highlights need to pay more attention to the content and public's need besides embracing other available social media tools and technologies to promote trust amongst the public and the organization. And also, need to devise means of adjusting to the inevitable changes regularly besides diverse approaches in strengthening $\mathrm{PR}$ practice and regulation.

16| This work is licensed under a Creative Commons Attribution 4.0 International License. 
East African Journal of Information Technology, Volume 3, Issue 1, 2021

Article DOI: https://doi.org/10.37284/eajit.4.1.502

APA CITATION

Samwel, N. N \& Lando, A. L. (2021). An Analysis of Social Media Usage by Public Relations Departments in Select Private Universities in Kenya. East African Journal of Information Technology, 4(1), c. https://doi.org/10.37284/eajit.4.1.502

\section{CHICAGO CITATION}

Samwel, Nyabera \& Agnes Lucy Lando. 2021. “An Analysis of Social Media Usage by Public Relations Departments in Select Private Universities in Kenya". East African Journal of Information Technology 4 (1), 16-25. https://doi.org/10.37284/eajit.4.1.502.

\section{HARVARD CITATION}

Samwel, N. N \& Lando A. L. (2021) “An Analysis of Social Media Usage by Public Relations Departments in Select Private Universities in Kenya”, East African Journal of Information Technology, 4(1), pp. 16-25. doi: 10.37284/eajit.4.1.502.

\section{IEEE CITATION}

N. N. Samwel \& A. L. Lando. "An Analysis of Social Media Usage by Public Relations Departments in Select Private Universities in Kenya", EAJIT, vol. 4, no. 1, pp. 16-25, Dec. 2021.

\section{MLA CITATION}

Samwel, Nyabera \& Agnes Lucy Lando. "An Analysis of Social Media Usage by Public Relations Departments in Select Private Universities in Kenya". East African Journal of Education Studies, Vol. 4, no. 1, Dec. 2021, pp. 16-25, doi:10.37284/eajit.4.1.502.

\section{INTRODUCTION}

This paper analyses the use of social media by Public Relations departments in two large private universities in Kenya. The paper is distributed into the following key sections: the background of the study; the methodology; the findings; the discussion besides, the conclusions

\section{Background to the Study}

On the study background, we concisely analyse the literature on use of social in public relations and present pertinent information on the Kenyan context. Thereafter, a statement of the problem, followed by the research question, and finally the scope of the study.

\section{Defining social media and Public Relations}

Social media encompasses online skills, rehearses, or else communities used by people in generating ideas plus sharing views, comprehensions, knowhows besides viewpoints with all (Television Bureau of Advertising, Inc, 2009). The tools include Social Networking Sites (SNS) for instance Facebook plus other networks of small computer blogging like twitter (Hopkins, 2014). Social media offers communication a path from the public to the organization and vice versa, thus translating to twoway communication
Public Relations practice is thus, a fundamental intermediary among organizations. Public Relations practitioners are accorded a sole chance of gathering data, checking public view on issues, in addition to charming their public's indirect discourse concerning varied issues by the internet (McAllister $\&$ Taylor, 2007). Internet growth in the $21^{\text {st }}$ century remains of utmost noteworthy expansions in lieu of media. For the organization to succeed, there is a dire need to consider the key stakeholder's opinions, for instance: the investors; the employees; the consumers; the stakeholders; and, other community associates in the organization's locality.

Professionals and scholars in communication studies have therefore emphasized that it is vital developing and implement social media strategies (Wong et al., 2005). Thus, the enhancement and comprehension of virtual communiqué through social media tools in PR is nevertheless unavoidable in the modern world. Grunig and Hunt (1984) emphasized the importance as well as the value of two-way communication in emergent reciprocal public-organization comprehension, mutually outwardly as well as inwardly.

Therefore, in view of this, many organizations have employed social media in their communication, but how such sites are being used has not been adequately and empirically investigated in Kenya (Gorman and McLean, 2009). 


\section{Statement of the Problem}

Today's the Public Relations Practitioners are in charge of developing strategies and implementing the techniques across a wide variety of platforms to address the needs of their publics. As technology and globalization evolve, so do the role of the Public Relations officers as well as the connotation of social media.

Social media use is constantly- growing amid organizations as well as public organizations. In addition, $67 \%$ of business and management organizations are utilizing social media (Martin, 2009). Furthermore, a noted success of social media use in investor relations Eisenhardt (Eisenhardt and Graebner, 2007). Moreover, improvement of government agencies in their Public Relations goals via social media (Facebook specifically) (Yin, 2008). In Kenya, previous researches have confirmed that social media take the capability to fetch about variations in public administration, heighten movement of information and service provision. Precisely, Neill et al. (2016) acknowledged the power of the internet in changing the power balance between an organization and its publics hence guaranteeing symmetric two-way exchange of information.

Despite the availability of social media platforms used, little is known on how Facebook, WhatsApp, and Twitter are used to communicate with their publics. Nevertheless, even in the perspective of higher learning institutions, there are indications of wide-ranging application of social media by Public Relations practitioners in their PR by different corporations in Kenya. These setups called for a study on use of social media in public relations, to generally investigate the use of WhatsApp, Facebook, and Twitter by public relations departments in private Universities

\section{Research Question and Scope of the Study}

In the understanding of the problem specified above, in the study stated in this paper, we pursued to address one research question:

How are Kenyan Private Universities using WhatsApp, Facebook, besides Twitter in their communication with their publics?
In relation to the scope of this research applicable to this paper, we sought to establish: how social media were used across organizations, the effectiveness of social media effectiveness, and to find out if social media helped organizations in engaging with their publics. In relative to the limitations, evidently, the study was constrained in relation to the content as it only focused on WhatsApp, Facebook, and Twitter. It is quite understandable that in organizations more so higher learning institutions, there were foreseeable commonalities between traditional and new media aspects of communication. It would therefore be more elevating to cover both media. Secondly, this paper covered only two private Universities (University K and St Paul University). It would conceivably have been more revealing to get insights on social media usage in other establishments, additionally, in relation to the context, this research was visibly solely circumscribed to the Nairobi cosmopolitan. Once more, it may well have been enlightening to cover more private Universities in the country. Thus, it is critical to clarify that the limits upstretched in this research were inescapable in any academic study which was restricted in relation to time as well as resources. Thus, this situation dictated for a restricted scope in terms of context, content in addition to methodology. Nonetheless, the rigor employed in the accomplishment of the designated scope was exhaustive adequate to guarantee the outcomes remained academically viable.

\section{LITERATURE REVIEW}

The current literature nevertheless has fundamentally leaned towards the western viewpoint with limited journal articles concentrating on precise expanses of the sphere. This paper, therefore, endeavours to contribute to the prevailing literature as well as gaze at the inclinations precise to the Kenyan scenario.

Social media is not a relatively novel phenomenon in Kenya since progress to the advancement of in effect communication in organizations with their inner and external publics has been laid in place in the modern times. The evolution has climaxed in the presentation of administrative plans besides regulations interconnected to day-to-day communication and public relations. However, less 
is known on how private Universities are using these sites in engaging with their publics.

In pursuit of the goal of social media use in public relations within organizations. Public relations have been left with no option other than adopting these sites in lieu of reaching their publics. Social media have therefore been consistently seen through higher learning organizations in Kenya. This move was critical especially after the Kenyan professionals and scholars in communication studies emphasized the need to develop and implement social media strategies (Wong et al., 2005).

Wright and Henson (2008 and 2013 conducted a longitudinal research focusing on the usage of emergent media in public relations. The study findings revealed that social media are being used by the public relations practitioners in their activities quite often, in addition to providing exceptional prospects for the publics and PR practitioners. Additionally, the results indicated that these novel media efficiently aid as an overseer for outdated news media, hence impacting the company besides administrative transparency as well as be in favour of apparent in addition to ethical culture. (Wright \& Hinson, 2013:14).

Alikilic and Atabek (2012) carried research in Turkey targeting the approval of social media amongst the Turkish PR specialists. A survey was adopted in the study using an online questionnaire directed to 158 Turkish Public Relations Association members (TUHID. The study findings resolved that the Turkish PR specialists have begun to expedite dialogs with their publics via social media (Alikilic and Atabek, 2012).

In addition, Wilson and Supa (2013) explored the effect of Twitter on the public relations-journalist. The study adopted a questionnaire covering 340 journalists and 291 public relations practitioners. The results indicated that the benefits of Twitter as an information-sharing platform were clearly recognized as important for both journalism and public relations.

In another study, Yoo and Kim (2013) studied online newsrooms use on the United States tourism websites. Content analysis was employed on 50 state tourism websites. The results indicated that "the average number of social media use by the 50 state tourism offices is 4.04 , and the most often used social media are Facebook (50 States), Twitter (49 States), YouTube (36 States), and Flickr (29 States)" (Yoo and Kim, 2013).

Moreover, Eyrich et al. (2008) carried out a research on "PR practitioners' use of social media tools and communication technology". The results revealed that almost six diverse social media tools have been embraced by the public relations practitioners

Likewise, Arnould (2017) conducted a research in Italian municipalities on targeting "Using Social media to engage citizens and specifically to examine how social media contribute to public engagement. The results concluded that Facebook and Twitter were used by municipalities to engage citizens besides there was a need for public administrations to move from a general isomorphic social media adoption to a thoughtful media strategy" (Agostino, 2013). Furthermore, the rise of novel media has led to the growth of PR practice (van der Merwe et al., 2005). Considering that organization's use of PR is growing exponentially with social media.

In summary, based on the previous literature, the Public Relations departments' social media use is rising immensely and at a fast stride over the past years. With the emergence of additional social media forms, a number of organizations are embracing novel communication techniques with their internal and external publics as well as stakeholders. And hence, disseminating information in the digital age is easy, fast, as well as more effective. Public relations has embraced social media right from initiation, the Public Relations practitioners see social media positively with reverence to planned communication. However, how these social media are being used by private universities in Kenya remains scanty and hence need for this study.

\section{METHODOLOGY}

This research was grounded within the mixed methods research, which provides several benefits to researchers (Bryman, 2012). Mixed methods are intended to counterbalance the weakness of a lonely method besides representing the strengths of both. 
Cutlip (2006) defines the mixed method in terms of research methodology that scientifically integrates both qualitative and quantitative methodologies in a sole study. Quantitative and Qualitative data were merged in light of availing an in-depth analysis of the research problem. Qualitative data was sought from senior management in charge of Public Relations and communication besides quantitative data drawn from students.

\section{Location of the Study}

This research was carried out in private Universities in the Nairobi region of Kenya in two select Universities (St Paul University and University K). These private Universities were selected based on the assumption that they had established communications departments, they were among the fully chattered private Universities and also represented other higher learning institutions in the Kenyan region, hence making it a hypothetically sufficient area for study in line with the issue under inquiry.

\section{Target Population}

The target populace for the qualitative interviews comprised of senior management in the custody of communication as well as Public Relations in University K and St Paul University respectively. Whereas, the quantitative analysis involved $10 \%$ of the students from each year of study and faculties in both institutions (University K 1500, and St Paul University 1200). The Public Relations and communication practitioners served as key informants whereas students served as main respondents.

\section{Sampling Technique}

Sampling is the practice of choosing and studying a sub-set from a population to obtain information regarding a phenomenon (Somekh and Lewin, 2005). In attaining the right and good sample size, the researcher adopted both purposive and stratified sampling. The students were chosen by the use of stratified sampling, which guaranteed equal chances of participation in line with years of study and faculty. Whereas, the Public Relations and communication practitioners were purposefully sampled since they were key informants for the study.

\section{Sampling Size}

In order to arrive at the appropriate size of the students. $10 \%$ of the total number of students in the two selected Universities was applicable, which was $10 \%$ of (1500 students from University K and 1200 students from St Paul University), making a total of 270 respondents in the two institutions respectfully.

\section{Research Instruments}

We primarily adopted questionnaires and interviews as data research instruments. Primary qualitative data was sought using face-to-face in-depth interviews with purposively chosen Public Relations and communication practitioners at both Strathmore and St Paul University. We employed in-depth Interviews so as to source for qualitative data besides targeting the respondents' real opinions on the research problem (Kelleher \& Brinkmann, 2009). While we employed questionnaires for students on the fact that they were senders and recipients of information in social media in the University and thus could provide different viewpoints on social media use in public relation (Somekh \& Lewin, 2005). The suitability of the questionnaire largely revolved around its convenience, reliability, and validity in the provision of targeted answers.

\section{Data Analysis}

Data presentation was systematic and descriptive in manner. The quantitative analysis involved numeric measures to the tallies from varied reactions proceeding social media use in Public Relations, tables and bar graphs were used in presenting data via frequencies and percentages besides interpretations of data was guided by research objective and analysed via SPSS, whereas, qualitative data analysis involved details from empirical literature that was thematically analysed in line with the research question.

\section{Ethical Considerations}

In terms of ethics, permission was sought from the applicable administrative authorities so as to gain entrance to the physical sites besides respondents before embarking on collecting data. We developed an informed consent form for the study respondents before involving them in the research Creswell 
(2009), recognizing the fact that the participants' rights could be protected, guaranteed anonymity, and kept their names confidential.

\section{RESULTS AND DISCUSSION}

The first objective that guided the research was to investigate Social Media usage by Public Relations departments in Selective Private Universities in Kenya.

Table 1: Response rate for the two Institutions

\begin{tabular}{llll}
\hline Institution & $\begin{array}{l}\text { Responses } \\
\text { Actual responses }\end{array}$ & Non-responses & Total \\
\hline St. Paul & $119(44.1 \%)$ & $1(0.4 \%$ & $120(44.4 \%)$ \\
University K & $150(55.6 \%)$ & $0(0.0 \%)$ & $150(55.6 \%)$ \\
Total & $269(99.6 \%)$ & $1(0.4 \%)$ & $270(100.0 \%)$ \\
\hline
\end{tabular}

For the purpose of this research, 270 questionnaires University (120). The table above shows the were administered to the respondents from the two distribution of respondents.

Universities, University K (150), while St Paul

Table 2: Demographic data for questionnaire respondents in both Institutions

\begin{tabular}{lllll}
\hline Variable & Values & St. Paul & University K & Total \\
\hline Gender & Male & $47.90 \%$ & $68.00 \%$ & $59.10 \%$ \\
& Female & $52.10 \%$ & $32.00 \%$ & $40.90 \%$ \\
\hline Age & Under 20 & $27.70 \%$ & $36.00 \%$ & $32.30 \%$ \\
& $21-30$ & $45.40 \%$ & $49.30 \%$ & $47.60 \%$ \\
& $31-40$ & $18.50 \%$ & $12.00 \%$ & $14.90 \%$ \\
& $41-50$ & $5.90 \%$ & $2.00 \%$ & $3.70 \%$ \\
& Above 50 & $2.50 \%$ & $0.70 \%$ & $1.50 \%$ \\
\hline Nationality & Kenya & $94.10 \%$ & $3.00 \%$ & $97.40 \%$ \\
& Ethiopia & $4.20 \%$ & & $0.70 \%$ \\
\hline
\end{tabular}

From Table 2 above, the majority of the respondents were male $(59.1 \%)$ aged between 21 to 30 years $(47.6 \%)$ and of Kenyan nationality (97.4\%).

21| This work is licensed under a Creative Commons Attribution 4.0 International License. 
Social Media Use by Select Kenyan Private Universities in their Communication with their Publics

Figure 1: Agreement on Facebook Use.

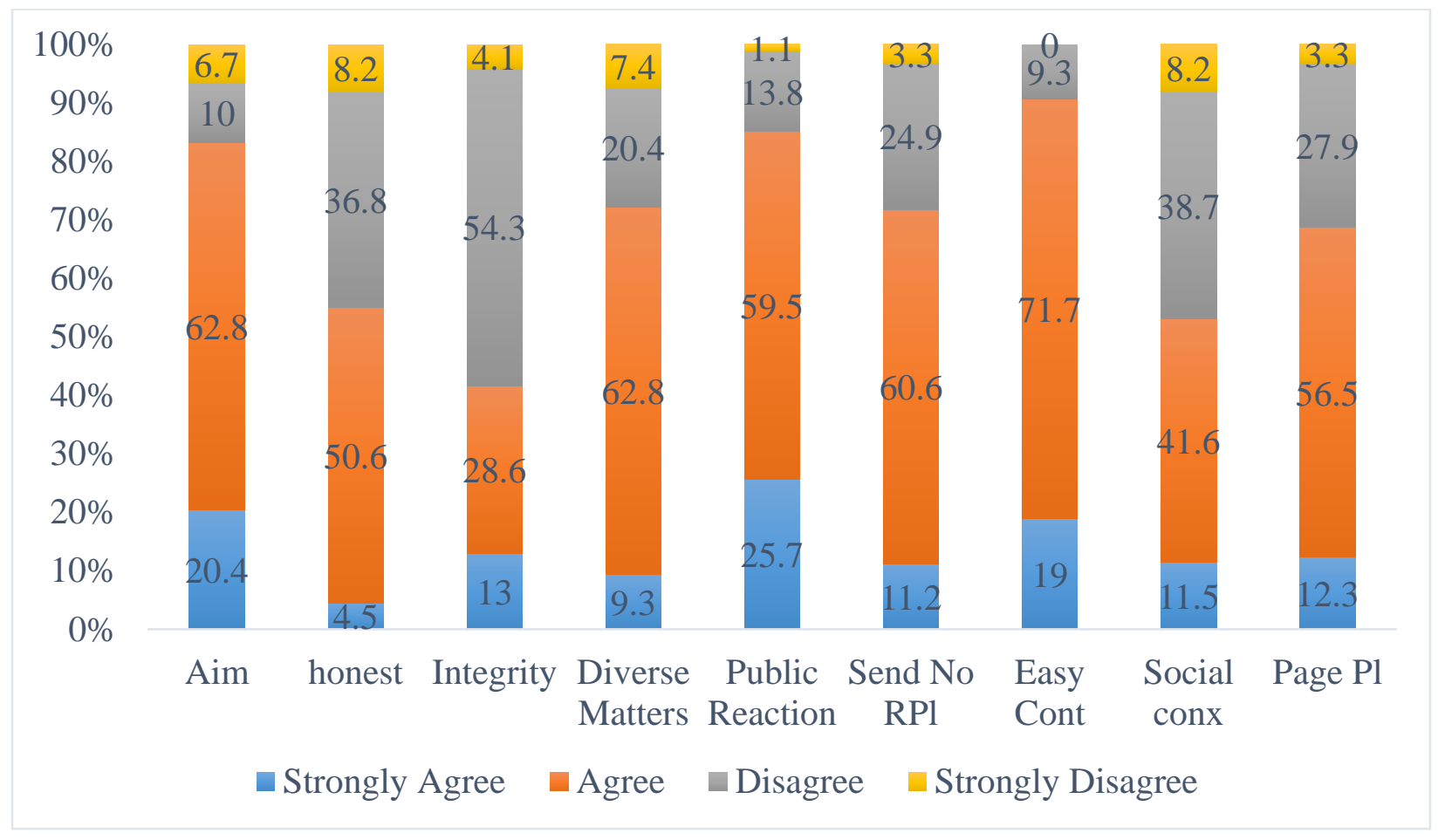

Figure 2: Agreement on WhatsApp Use

$22 \mid$ This work is licensed under a Creative Commons Attribution 4.0 International License. 


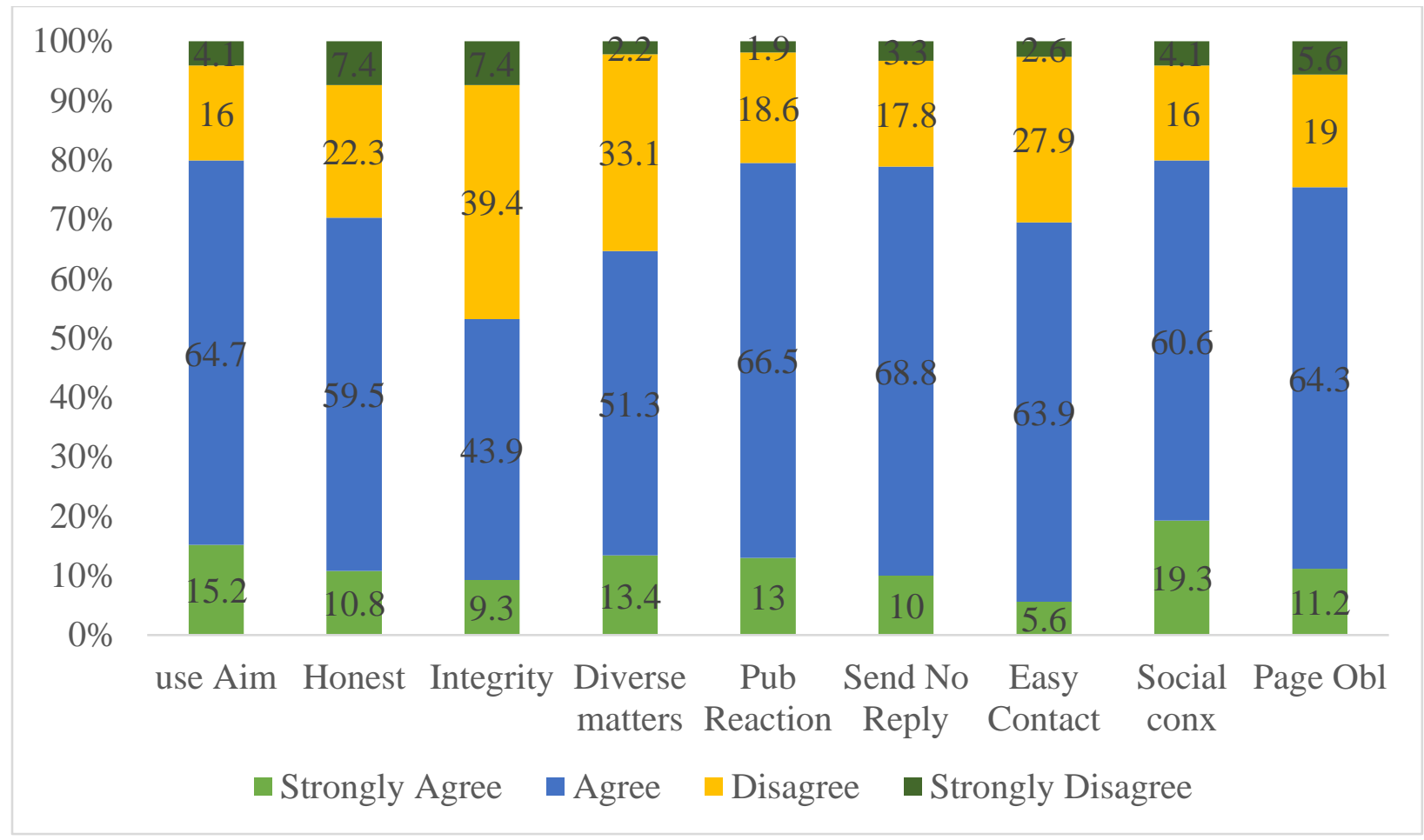

Figure 3: Agreement on Twitter Use.

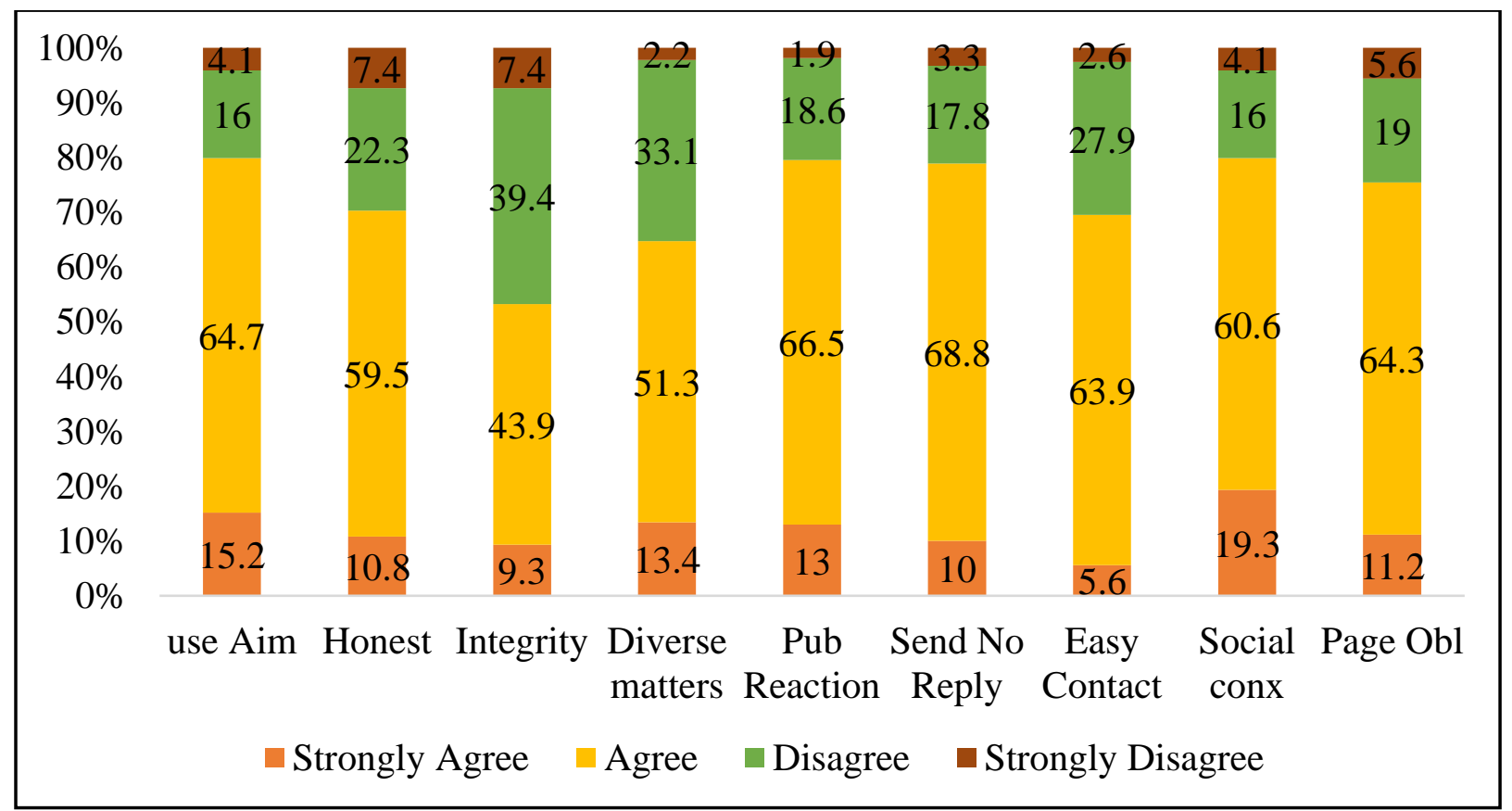

Figures 1, 2, and 3 above on agreement on Facebook, Twitter, and WhatsApp use. The prompt on assisting the public see the organization's position from diverse matters. Generally, with regard to the outcomes of this study as presented in the above-mentioned segment, the study discloses that evidently with regard to assisting the public in supporting and seeing the organization's position in

23| This work is licensed under a Creative Commons Attribution 4.0 International License. 
diverse matters the questionnaire sent via Facebook appealed to the majority of the respondents $(72.1 \%)$, with $(64.7 \%)$ Twitter respondents besides WhatsApp appealing to $(64.7 \%)$ respondents. Hence a suggestion that WhatsApp as well as Twitter were used by the respondents articulately in assisting the public in supporting and seeing the organization's position in diverse matters

As reported in the findings, engaging in dialogue with their publics concerning their activities it also emerged that $(83.2 \%)$ of the respondents were Facebook users, while (79.9\%) respondents were twitter users while $(79.8 \%)$ respondents were using WhatsApp. with the majority of Facebook respondents (84.7\%) being from St Paul University. On the other hand, tweeter attracted the majority of respondents (78.6\%) from Strathmore University while the majority of WhatsApp respondents (92.4\%) were from St Paul University. Interestingly, Strathmore University recorded the lowest respondents (34\%) on WhatsApp, an indication associated with the fact that WhatsApp was not yet an official communication platform for the University as far as communication is concerned, and hence minimal usage.

Another key finding was that $(71.8 \%)$ respondents agreed to use Facebook to send information to the public, while $(78.8 \%)$ respondents used Twitter whereas $(77.8 \%)$ respondents used WhatsApp.

From an in-depth interview on the senior management in charge of communication and PR from the two institutions. The study reveals that social media use was part of communication by the Public relations practitioners particularly in reaching their publics on varied issues. And this concurred with (Sweetser \& Metzgar, 2007; Trammell \& Keshelashvili, 2005) that social media is used by several organizations in strengthening relationships with their publics. In addition, it emerged that University $\mathrm{K}$ is further aggressively involved in Public Relations activities over social media. This was based on the fact that University $\mathrm{K}$ had more human resources linked to digital media operations and media affairs, for instance, WhatsApp, Twitter besides Facebook likened to St Paul University.

Additional significant outcome worth deliberating more is the question of a dedicated public relations office in University $\mathrm{K}$ majorly designated with social media and online communication. It emerged that University $\mathrm{K}$ had more chances of being active compared to St Paul University. Thus, embracing digital communication quite often than conventional communication in their day-to-day activities. This concurs with the earlier survey from students on the use of these sites in communicating with their publics.

\section{CONCLUSION}

Overall, this paper has investigated the use of Social Media in the Public Relations departments in Private Universities in Kenya.

The study reveals that the main use of social media in PR by the two institutions include: to provide a question-and-answer platform for the public to publicize activities; to send public information; to lobby public support; to change public opinion as well as to enhance information value. It is thus practical to settle that despite the fact that social media are significant in public relations in addition to communication studies in general. The public relations practitioners of Kenyan private Universities contributing to this study proved doubt to social media usage in their public relations practice which is quite related to the inclination known anywhere else in the domain. Whereas they recognized social media benefits in enhancing overall speed besides facilitating direct communication with their publics, they were likewise concerned about the time pressure put forth by social media on public relations roles besides the minimal control above the information disseminated with regards to universities they represented

\section{Recommendations}

Based on this, we therefore recommend that, there is need for the management at the two institutions, to pay more attention to the content and public's need besides embracing other available social media tools and technologies to promote trust amongst the organization as well as its publics. The organization's PR practitioners should also devise means of adjusting to the inevitable changes regularly to institute changes in line with PR professional bodies. Additionally, education 
practitioners' specifically in higher learning education ought to sightsee further efficient and innovative means of incorporating social media use in elevating the quality of learning at institutions of higher learning institutions by application of elearning.

\section{REFERENCES}

Agostino, D. (2013). Using social media to engage citizens: A study of Italian municipalities. Public Relations Review, 39(3), 232-234.

Alikilic, O., \& Atabek, U. (2012). Social media adoption among Turkish public relations professionals: A survey of practitioners. Public Relations Review, 38(1), 56-63.

Arnould, V., Strazzari, F., Kokko, L., Stang, G., Tor, A., Vervaeke, A., \& Vines, A. (2017). African futures. Horizon, 2025.

Bryman, A. (2008). Why do researchers integrate/combine/mesh/blend/mix/merge/fuse quantitative and qualitative research. Advances in mixed methods research, 21(8), 87-100.

Bryman, A. (2012). Social research methods, 4th Ed. Oxford, UK: Oxford University Press.

Creswell, J. W. (2009). Research design: Qualitative, quantitative, and mixed methods approaches $\left(3^{\text {rd }}\right.$ ed.). Thousand Oaks, CA: Sage Publications Ltd.

Cutlip, S.M., Center, A.H., \& Broom, G.M. (2006). Effective public relations. Upper Saddle River, NJ: Pearson Education Inc.

Ellison, N. B., Steinfield, C., \& Lampe, C. (2007). The benefits of Facebook "friends:" Social capital and college students' use of online social network sites. Journal of computer-mediated communication, 12(4), 1143-1168.

Eisenhardt, K. M., \& Graebner, M. E. (2007). Theory building from cases: Opportunities and challenges. Academy of management journal, 50(1), 25-32.

Eyrich, N., Padman, M. L., \& Sweetser, K. D. (2008). PR practitioners' use of social media tools and communication technology. Public relations review, 34(4), 412-414.

Gorman, L., \& McLean, D. (2009). Media and society into the 21st century: a historical introduction. John Wiley \& Sons.

Grunig, J.E., \& Hunt, T. (1984). Managing public relations. Beverly Hills, CA: Wadsworth/Thomson Learning.

Hopkins, K. (2014). The phatic nature of the online social sphere: Implications for public relations. PRism, 11(2), 1-12.

Kelleher, T. (2009). Conversational voice, communicated commitment, and public relations outcomes in interactive online communication. Journal of communication, 59(1), 172-188.

McAllister, S. M., \& Taylor, M. (2007). Community college web sites as tools for fostering dialogue. Public relations review, 33(2), 230232.

Martin. R., Oliver. S., \& Jacquelyn, B. (2009). Customer relationship management and firm performance: the mediating role of business strategy, Journal of the academy of marketing science. 1, (3), 326-346.

Neill, M. S., \& Lee, N. (2016). Roles in social media: How the practice of public relations is evolving. Public Relations Journal, 10(2), 1-25.

Sweetser, K. D., \& Metzgar, E. (2007). Communicating during crisis: Use of blogs as a relationship management tool. Public Relations Review, 33(3), 340-342.

Somekh \& Lewin. (2005). Qualitative interviewing: the art of hearing data $\left(2^{\text {nd }} e d.\right)$. London: Sage Publications

Television Bureau of Advertising, Inc. (2009). Multiplatform Glossary. Retrieved November 11, 2009, from Television Bureau of Advertising: http://www.tvb.org/multiplatform/ Multiplatform_Glossary.aspx

Trammell, K. D., \& Keshelashvili, A. (2005). Examining the new influencers: A selfpresentation study of A-list blogs. Journalism \& 
Mass Communication Quarterly, 82(4), 968982.

Van der Merwe, R., Pitt, L. F., \& Abratt, R. (2005). Stakeholder strength: PR survival strategies in the Internet age. Public Relations Quarterly, 50(1), 39.

Wright, D. K., \& Hinson, M. D. (2008). How blogs and social media are changing public relations and the way it is practiced. Public relations journal, 2(2), 1-21.

Wright, D. K., \& Hinson, M.D. (2013). Examining social and emerging media use in public relations practice: A ten-year longitudinal analysis. Public Relations Journal, 9 (2) 1

Wright, D. K., \& Hinson, M. (2014). Examining how social and other emerging media are being used in public relations. Retriev. Novemb, 12, 2014.

Wilson, J. (2014). Essentials of business research: A guide to doing your research project. Sage.

Wong, B. K., \& Lai, V. S. (2005). Examining task social presence and its interaction effects on media selection. The Business Review, Cambridge, 3(2), 135-142.

Yin, R. K. (2003). Case study research design and methods $\left(3^{\text {rd }}\right.$ ed.). London: sage publications.

Yoo, K. H., \& Kim, J. R. (2013). How US state tourism offices use online newsrooms and social media in media relations. Public Relations Review, 39(5), 534-541. 